\title{
12 RASTAFARI PERSPECTIVES ON LAND USE AND MANAGEMENT IN POSTCOLONIAL ZIMBABWE
}

\section{Fortune Sibanda ${ }^{1}$}

\section{INTRODUCTION}

Globally, the land question remains paradoxical as it is heavily steeped in racial, gender, class, ethnic, regional, national and international controversies. In Southern Africa, Zimbabwe provides a typical example of how the land question forms a crucial part of a people's history since all the three Chimurenga wars ${ }^{2}$ were the result of issues pertaining to land. ${ }^{3}$ Indeed, land is regarded as the mainstay of the country's economy. In contemporary parlance of ZANU-PF, "the economy is land and land is the economy". ${ }^{4}$ In recent years, Zimbabwe embarked on the controversial Land Reform Programme (LRP) that was championed by the government as a way of reclaiming a lost heritage and empowering the black majority. The LRP, which placed Zimbabwe under the spotlight, is arguably justified as part of the government's call to "indigenise, empower, develop and create employment" for the benefit of the entire nation. ${ }^{5}$ Nevertheless, close to two decades after the commencement of the Third Chimurenga in 2000, ${ }^{6}$ the land question remains a contested part of the Zimbabwean heritage with regard to the issue's ownership, use and

1 Fortune Sibanda holds a Doctorate in Religious Studies from the University of Zimbabwe. He lectures in the Department of Philosophy and Religious Studies, Great Zimbabwe University, Masvingo.

2 Chimurenga is a Shona term which means a war of liberation. The First Chimurenga lasted from 1896 to 1897; the Second Chimurenga war from 1965 to 1979; and the Third Chimurenga was characterised by land invasions that commenced in 2000 and culminated in the Land Reform Programme.

3 See, for example, Sibanda F and Maposa R. 2014. "Beyond the Third Chimurenga?: Theological Reflections on the Land Reform Programme in Zimbabwe", The Journal of Pan African Studies 6(8), March:54-74. The phrase "Beyond the Third Chimurenga", which is part of the title, refers to the period following the government command to discontinue with illegal land invasions.

4 Team ZANU-PF. 2013. The People's Manifesto 2013: Taking Back the Economy Indigenise, Empower, Develop \& Create Employment. Harare: ZANU-PF, 31. See also Mugabe RG. 2001. Inside the Third Chimurenga: Our Land is Our Prosperity. Harare: Department of Information \& Publicity, Office of the President and Cabinet.

5 See, for example, Team ZANU-PF. 2013. The People's Manifesto 2013; Chirenje G. 2015. "Indigenise, Empower and Develop!”, News Day, 4 August. In essence, the Land Reform Programme was meant to rationalise land ownership between the white minorities who formed 0.6 percent of the population, yet still possessed over 70 percent of the fertile land, to the detriment of the black majority. See also Dube Musa W. 2015. "A Luta Continua: Toward Trickster Intellectuals and Communities", Journal of Biblical Literature 134(4):890-902, (894).

6 The Third Chimurenga started in February 2000 when a communal initiative of the people under leadership of Chief Enock Zenda of Svosve in Mashonaland East 
management. Apparently, during the so-called jambanja phase, ${ }^{7}$ a high degree of euphoria associated with land redistribution to the dispossessed black majority manifested, resulting in reckless cutting of trees and incidents of veld fires with impunity by varimi vatsva (the new indigenous farmers) that destroyed natural resources on former white-owned farms. Therefore, the debates on land use and management have attracted the attention of different players, such as agricultural scientists, economists, social and political scientists, literary artists and feminists. This study seeks to contribute to the existing discourse in religious studies on the land issue by focusing on Rastafari. ${ }^{8}$

Specifically, this chapter examines the perspectives of Nyahbinghi Rastafari communities on land use and management in postcolonial Zimbabwe. Rastas in Zimbabwe are an often forgotten and misunderstood Pan-African New Religious Movement, which, nevertheless, is a cardinal player in the land issue on the basis of their contribution to the country's political liberation. Rastas are sometimes located at the margins and have had to grapple with some negative stereotypes in society. ${ }^{9}$ However, a lot can be gleaned from the "Rastafari green philosophy"10 that encompasses the principle of Ital livity ${ }^{11}$ to the backdrop of

Province forced the government to embark on a revolutionary land resettlement programme that resulted in the LRP.

7 Jambanja phase refers to the period when there were haphazard and unpredictable incidents of land seizure from white commercial farmers during the Third Chimurenga, or hondo yeminda (war for the land) as it was also known.

8 Etymologically, the term 'Rastafari' is derived from the combination of Amharic words Ras (prince, duke, lord) and Tafari. In its original use, "Ras Tafari" was the name of His Imperial Majesty (H.I.M.) Emperor Haile Selassie I, who was born as Lidj Tafari Makonen in 1892 and crowned Emperor of Ethiopia on 2 November 1930. In general, Rastafari is the name of the movement and at the same time it is the name of the followers of the movement itself. The adherents deify Emperor Haile Selassie I (referred to as Jah Rastafari) and the religion as well as followers is named after H.I.M. The study uses the term Rastafari to refer to both the religion and those who practise it, notwithstanding that the practitioners are also identified as "Rastafarians" and the short form, "Rastas". See, for example, Salter R. 2008. "Rastafari in a Global Context: Affinities of 'Orthognosy' and 'Oneness' in the Expanding World", IDEAZ 7. Special Issue on "The Globalization of Rastafari", 10-27.

9 In most societies, Rastafari are one of the most misunderstood groups and people tend to be sceptical of Rastas. They are sometimes described as "dagga-smokers" (marijuana smokers) and good-for-nothings. See, for example, Sibanda F. 2015. "'Legalise It!': Re-thinking Rastafari-State Relations in Postcolonial Zimbabwe", in Coertzen P, Green MC and Hansen L(eds). Law and Religion in Africa: The Quest for the Common Good in Pluralistic Societies. Stellenbosch: African Sun Media, 185-205. See also Salter, "Rastafari in a Global Context", 10.

10 Sibanda F. 2015. "Rastafari Green Philosophy for Sustainable Development in Postcolonial Zimbabwe: Harnessing Eco-theology and Eco-justice", in Chimhanda FH, Molobi VMS and Mothoagae ID (eds). African Theological Reflections: Critical Voices on Liberation, Leadership, Gender and Eco-Justice. Pretoria: Research Institute for Theology and Religion, UNISA, 187-206.

11 "Ital" or "I-tal" comes from the words "vital" or "total". It is employed when referring to food, meals, environment, social atmosphere, or way of living that is wholesome, organic, lively and hence nourishing and healthy. "Livity" refers 
climate change and the widespread use of chemical fertilisers by beneficiaries of the LRP in Zimbabwe. The chapter argues that organic, conservative farming and natural living, which Rastafari advocate, are vital in protecting the productivity and cleanliness of the land heritage for present and future land users in Zimbabwe. In other words, land justice has become an urgent agenda for action, not merely in terms of its ownership, but also in its sustainable use and management.

\section{THEORETICAL FRAMEWORK AND METHODOLOGY OF STUDY}

This study benefited from the insights of the Afrocentric theory. This Africancentred theory, also known as Afrocentricity, is associated with Pan Africanist scholars, such as Molefi Kete Asante, who advocated and popularised the Afrocentric genre. In essence, Afrocentricity is a response to the derogatory Western scholarship on Africa, Africans and their cultural heritage. The broader intellectual aim of Afrocentricity is to challenge and deconstruct Eurocentric denial and misrepresentation of African history and culture. ${ }^{12}$ It is believed that Western writers and colonialists conveyed a pessimistic perspective on African culture, religion and heritage. African heritage, culture and religion were often misunderstood, misrepresented, distorted and displaced. ${ }^{13}$ This created a philosophy of the centre and the periphery which placed Western culture at the centre whilst African culture and heritage were assigned to the margins. ${ }^{14}$ This demanded a deconstruction process to be applied in the reclamation of African culture, African heritage, African philosophy, African history, African indigenous religion as well as African land. Along these lines, Asante says Afrocentricity calls for "collective consciousness" among African people, where "all African phenomena, activities and ways of life to be looked at and given meaning from the standpoint and worldview of Africans." 15 Therefore, with Rastafari being Afrocentric in orientation, the Afrocentric theory is ideal for exploring Rastafari perspectives on land use and management. This is because Afrocentricity "stands as both a corrective and a critique"16 to the attitudes and

to one's quality of life, or livelihood that a person or other living things possess. Thus, "Ital livity" is a natural lifestyle that encompasses organic farming, food and diet. See Dickerson MG. 2004. I-tal Foodways: Nourishing Rastafarian Bodies, MA Thesis, Department of Geography and Anthropology, Louisiana State University \& Agricultural and Mechanical College, 156. Online at: http://etd.Isu.edu/docs/ available/etd-06022004-174954/unrestricted/Dickerson_thesis.pdf

12 Adeleke T. 2009. The Case against Afrocentrism, Jackson: University Press of Mississippi, 10.

13 See Mndende N. 1999. "From Racial Oppression to Religious Oppression", in Walsh TG and Kaufmann F (eds). Religious and Social Transformation in Southern Africa. Minnesota: Paragon House.

14 Sibanda F. 2011. African Blitzkrieg in Zimbabwe: Phenomenological Reflections on Shona Beliefs on Lightning. Saarbrucken: LAP, 2.

15 Asante MK. 2007. An Afrocentric Manifesto: Toward an African Renaissance. Malden: Polity.

16 Asante, An Afrocentric Manifesto, 27. 


\section{Heritage of Land, Water and Great Zimbabwe}

actions of past and present generations with regards to the land question in Zimbabwe. The corrective element targets the distortions of land distribution and use in the colonial and postcolonial times in Zimbabwe given that Rastafari is interested in ensuring land justice. As a critique, the Afrocentric theory sensitises beneficiaries of the land redistribution to use and manage natural resources in a sustainable way.

This study utilised a poly-methodic approach. In order to collect data, the study used in-depth interviews conducted with information-rich Nyahbinghi Rastafari members, who were purposively sampled from the Marcus Garvey Nyahbinghi Rastafari House in Epworth, Chaminuka Nyahbinghi Rastafari House in Chitungwiza, Marondera Nyahbinghi Rastafari House in Marondera and Dzimbadzemabwe Nyahbinghi Rastafari House in Glen Norah. Participant observation was also used as a data collecting technique. The latter was useful in two ways: On one hand, the researcher was exposed to some homestead gardens and patchy maize field portions cultivated under the urban agricultural land use from open spaces of municipal land. On the other hand, the researcher participated in so-called Rastafari Reasonings where the subject of land was discussed. The study also benefited from a documentary analysis of the print and electronic media of newspapers and television captions as well as from Nyahbinghi Rastafari archival documents that included photographs, brochures and songs.

The study also benefited from the insights of a corroboration of the historical, sociological and phenomenological approaches to describe and interpret data. The historical method involves hermeneutics and has a complementary relation with the phenomenology of religion on the basis of anti-reductionism that promotes the insider perspective. The historical approach was ideal for the study in tracing the history of the land question and bringing out the way Rastafari communities understand the issue in Zimbabwe. The study tapped into phenomenological principles such as epoche (bracketing out), descriptive accuracy, eidetic intuition (establishing the meaning) and comparison. Although the sociological method is often accused of reductionism in the study of religion, the research found it useful in as much as the sociological themes in relation to religion enhanced understanding of the dynamics of the land question in Zimbabwe on the basis of class, gender, creed and political affiliation. On the whole, a Rastafari hermeneutics was useful in offering a critique on land ownership, use and management in Zimbabwe.

\section{HISTORICAL BACKGROUND OF RASTAFARI IN ZIMBABWE}

Rastafari, a religio-political movement of Jamaican origin, has a fairly long history of existence. It is regarded as a Pan-Africanist and Ethiopianist movement that arose among oppressed, marginalised black former slaves in Jamaica, influenced by the ideas of people such as the Jamaican-born 
philosopher and Pan-Africanist, Marcus Garvey. ${ }^{17}$ Today, Rastafari has grown and spread to become a global phenomenon partly through the contribution of the reggae icon, Bob Marley. Rastafari is one of the religions in Zimbabwe whose emergence may precede the independence of the country in 1980, but whose membership and popularity was arguably accelerated with the coming of the Rastafari revolutionary reggae doyen, Bob Marley, to perform on independence eve. ${ }^{18}$ Through Bob Marley's music, Rastafari registered its partnership with Pan-African liberation revolutionary movements, including those of Zimbabwe. Rastafari is characterised by diversity between and among the Nyahbinghi, the Bobo Ashanti and the Twelve Tribes of Israel ${ }^{19}$ in both Jamaica and Zimbabwe. Nyahbinghi, which is at the centre of this chapter, is one of the major strands of the Rastafari movement in Zimbabwe that has several branches (houses) mainly in the major cities and towns. This makes it largely an urban phenomenon. The Nyahbinghi Rastafari houses that forms the focus of this study are based in Harare, namely, Marcus Garvey Nyahbinghi Rastafari House in Epworth, Chaminuka Nyahbinghi Rastafari House in Chitungwiza, Marondera Nyahbinghi Rastafari House in Marondera and Dzimbadzemabwe Nyahbinghi Rastafari House in Glen Norah. Among these houses, the Rastas are diverse in their orientation with some being so-called reggae Rastas, environmentalist Rastas and Rasta Italists. All these categories are linked to the Rastafari concern land justice in terms of ownership, use and management.

\section{RASTAFARI THEOLOGY OF LAND}

A Rastafari theology of land cannot be isolated from historical experiences such as the African holocaust perpetuated by the transatlantic slave trade, colonial rule and postcolonial contradictions, which were pivotal to Rastafari origins and ideological orientation. Rastafari, as a religio-political Pan-African movement, was also influenced by the ideas of Pan-Africanists such as Marcus Garvey's "back to Africa” call and prophecies about a black king and redeemer for black people. Following Garvey, the crowning of Haile Selassie as Emperor of Ethiopia on 2 November 1930 was regarded as a kairos moment for African liberation. Essentially, Marcus Garvey influenced the Rastafari African theology of liberation that made race consciousness and land justice central in the Godtalk of Africans in the diaspora. ${ }^{20}$ Through Rastafari, an African liberation theology anchored on African identity and land justice was formulated.

17 See, for example, Sibanda F. 2012. "The Impact of Rastafari Ecological Ethic in Zimbabwe: A Comparative Discourse", The Journal of Pan African Studies 5(3), June:59-76.

18 Sibanda, "Legalise It!".

19 Middleton DJN. 2015. Rastafari and the Arts: An Introduction. New York and London: Routledge, 2.

20 Hewitt R. 2016. "Stealing Land in the Name of Religion: A Rastafari ReligioPolitical Critique of Land Theft by Global Imperial Forces", HTS 72(1):a3347. Online at: http://dx.doi.org/10.4102/htsv72i1.3347 
In Rastafari philosophy, Ethiopia, Africa, Babylon, Zion and Jamaica are symbols that do not only refer to geographical and physical location but also to markers of ideological and psychological identity formation. ${ }^{21}$ Ethiopia and Africa are interchangeable in Rastafari worldview and they are sometimes referred to as "home", "the promised land" and "Zion", whilst Jamaica and Babylon signify places of oppression. The embrace of African land as Zion is the first step in any Rastafari theological reflection. As Roderick Hewitt, theology and ethics scholar, writes, "Rastafari's embracement of Ethiopia as the tangible expression for all of Africa is linked to a biblical reference about Ethiopia, the coronation of Haile Selassie as Emperor of Ethiopia and Garvey's teaching about the centrality of Ethiopia and Africa in the liberation of black people." 22 The above shows how Rastafari theology of land cannot be understood outside Africa and Ethiopia, in particular. The fact that Ethiopia remained uncolonised made it an ideal symbol for African independence and sovereignty. Therefore, the iconic red, gold and green colours of the Ethiopian Lion of Judah flag became a Rastafari emblem, as a way of identifying with Africa and its values. Along the same lines, repatriation of some Africans in the diaspora can also be conceived on this basis.

In the context of land justice, Rastas believe that land constitutes a fundamental resource which forms the identity of a people and the need to deconstruct the historical error on land dispossession by imperial forces. The importance of land is succinctly captured by the Zimbabwean historian, Henry Moyana, when he argues that land is vital for the dead, the living and the unborn..$^{23}$ In Zimbabwe, the colonial state alienated land through legislation forcing Africans to leave their historical ancestral lands and thereby propelling the emergence of three Chimurenga wars of liberation. The global Rastafari theology on land dovetails with the next section on land ownership, use and management among Rastas in Zimbabwe.

\section{LAND OWNERSHIP, USE AND MANAGEMENT IN THE PRISM OF RASTAFARI}

The issues surrounding land ownership, use and management are very critical in Rastafari. This is because Rastafarians have a high regard for a natural livity or Ital livity, which can be understood from their perspectives on natural land use and diet. Rastas need land to produce Ital food commensurate with their vegetarian diet and gregariousness with nature. Erin David, a Rastafari researcher, puts it succinctly, thus: "In practice, living naturally means producing one's own food, eating an Ital diet and, respecting the sacredness

21 Hewitt, "Stealing Land in the Name of Religion".

22 Hewitt, "Stealing Land in the Name of Religion".

23 Moyana HV 2002. The Political Economy of Land Question in Zimbabwe. Gweru: Mambo. 
of the Earth by refusing to use it commercially or to sell it for profit." ${ }^{24}$ The following subsections explore the different elements of Rastafari perspectives and experiences, namely, land ownership, land use and land management.

\section{Land ownership}

In Zimbabwe, land ownership is a complex phenomenon, but it is closely linked to official recognition and registration, which has affected the Rastafari movement whenever they wanted to acquire property, benefit from land allocation or publicly gather as an organisation. Therefore, it has to be asked: Can Rastas acquire and own land in Zimbabwe? In an interview, one Rasta elder had this to say:

In Zimbabwe, President Mugabe said that there is need for communal land for Rastas. However, he stressed that Rastas must first get organised before they are allocated land. [Yet] some Rastas say that we do not want to register because it will be dealing with Babylon. This shows that some have not yet come to terms with the reality that we are not in a foreign nation. Rastas see government as being there to administer on behalf of the people. It is not government but the people running it democratically. Eurocentricity is dividing people through church-state relations which is still strong where State is separate from Church rather than having State and Church working together in unity. Rastafari Churchical Order uses a Theocratic Reign ... ${ }^{25}$

A number of issues can be identified in the above narrative on Rastafari land ownership in Zimbabwe. The millenarian tendencies of some Rastafari members are evident from the above where the government leaders operate as politicians who cannot be trusted and thereby being dismissed as "Babylon". ${ }^{26}$ At the same time, some put trust in the government showing a shift from a position of isolation and non-involvement to one of political engagement through routinisation. ${ }^{27}$ Such Rastafari adaptation to contemporary realities is reminiscent of Bob Marley's advice through reggae music for the suffering and oppressed people to "Get up, Stand up! Stand up for your rights! [and

24 David E. 1998. “Nature in Rastafari Consciousness". Online at: https://debate. uvm.edu/dreadlibrary/david.html

25 Interview with a Rasta Elder, Harare, 30 December 2012.

26 "Babylon" generally refers to Western hegemony, but also to any system of oppression, both by whites or blacks. Politicians are not always trustworthy and they are often regarded as full of tricks - "polytricks". Edmonds EB et al. (1998. "Dread 'I' In-A-Babylon", in Murrell NS, Spencer WD and McFarlane AA (eds). Chanting Down Babylon: The Rastafari Reader. USA: Temple University Press, 2433) defines "Babylon" as "... that worldly state of affairs in which the struggle for power and possessions takes precedence over the cultivation of human freedom and concern for human dignity", p. 24. For Roderick Hewitt ("Stealing Land in the Name of Religion"), Babylon is life-denying and de-humanising. This is useful in understanding Rastafari views on land ownership in Zimbabwe.

27 Barnett 2012:292 cited in Hewitt, "Stealing Land in the Name of Religion". 
never to] give up the fight!" ${ }^{28}$ Indeed, in recent years, the Nyahbinghi Rastafari got registered by way of a notarial deed of trust, as the Nyahbinghi National Council in Zimbabwe.

The urgent need for land among Rastas has been summed up by the Zimbabwean roots reggae artist and Rastafarian elder, Man Soul Jah in one of his songs on the album Time, which featured the popular track, "Mr Government Man". ${ }^{29}$ In the song, Man Soul Jah chanted in part: "Mr Government Man ... Give me the land." "Mr Government Man" was released in 2000 and meant to express the landless people's demand for land as a right and source of livelihood and identity in Zimbabwe. Although this song received generous airtime on the local radio stations, and coming from a reggae artist being an avenue for spreading "Jah message to all humankind", the song resulted in him being ostracised for supporting the country's land reform programme. ${ }^{30}$ Although the majority of Nyahbinghi Rastas do not own land "beyond the Third Chimurenga", they support the motive behind the Land Reform Programme in Zimbabwe. In the eyes of many Rasta participants, the land reform programme characterised by jambanja (land invasion) was a justified struggle to reassert black indigenisation, empowerment, identity and independence.

In support of the LRP in Zimbabwe, one Rasta elder had this to say: "The white settlers took the land by force from our Ancients (elders) in the Ancient of Days. There is nothing wrong in taking back that land in the same way because it is rightfully ours. It's high time that we emancipate ourselves from mental slavery and indigenise through Rastafari." 31 Similarly, another elder said that the land reform is about reclaiming sovereignty lost to white colonialists and as well as black oppressors - the land barons who own multiple farms. On the basis of multiple farm ownership by the few fellow black elites, Rastas pronounce judgment and a message of denunciation to these contemporary oppressors - sometimes through reggae music or as the subject for dialogue at binghi $i^{32}$ (reasoning sessions held in different Rastafari houses every Sabbath). ${ }^{33}$

28 Bob Marley, 1973. “Get Up, Stand Up”, Burnin. Bob Marley and the Wailers.

29 Man Soul Jah was born as Joseph Tatenda Nhara. He is a station manager for the Zimbabwe Broadcasting Corporation's Voice of Zimbabwe Radio Station in Gweru.

30 Chakanyuka T. 2014. "Man Soul Jah, Prophet without Honour in His Town", Gweru Today, 16 January. Online at: https://www.facebook.com/nhasimugweru/ posts/733813733296809

31 Interview with a Rasta Elder, Masvingo, 20 February 2014.

32 Binghi refers to the ceremonial gatherings of Rastas at different shrine sites where they participate in ritual activities which they believe facilitate communion and spiritual healing. The binghis usually last for more than a day and are sometimes held to commemorate special days on the Rastafari calendar. There is also another sense in which binghi refers to the sacred space on which the shrine is located. Among other activities, Rastas engage in "reasoning", in which they participate in intense discussion to inspire and enlighten one another through dialogue.

33 The researcher was part of some of the dialogues held during binghi sessions on the subject of land. Rastas are forced to choose where they stand in this struggle 
Along the same lines, Ras John of Marcus Garvey House remarks that,

[1]and reform was good because it fulfils the views of Marcus Garvey that Africa is for the Africans both at home and abroad. Land is a basis of people's identity. Bloodshed is bad, but this was a justified war for the black majority. As far as I know, Rastas did not take part in jambanja physically but they supported the struggle heartically and spiritually through word, sound and power. Land is good because we need land for businesses, organic farming for ital food, building houses, tabernacles and setting up a Rasta community. Rastas condemn the corruption of multiple farm ownership and wish for equitable land distribution and full utilising the land. Rastas are into indigenisation but are not benefitting because of party politics. We also condemn reckless cutting down of trees by some newly settled farmers. ${ }^{34}$

Rastas call for economic emancipation, indigenisation and sustainable development partly through land ownership and farming as one critical area they see as vital for livelihood. The narrative of Ras John's also shows that most Rastas have not been among the beneficiaries of the land redistribution programme, partly because of politics. Given that the LRP was mainly spearheaded by ZANU-PF, it follows that Rastas who were non-partisan will not find it easy to get land, notwithstanding their pro-indigenisation ideology. In addition, some of the observations of Ras John concerning the abuse of natural resources through the wanton cutting down of trees by some newly settled farmers will be revisited under the subsections on land use and management.

\section{Land use}

As has been hinted above, Rastafari perspectives on land use are guided by the Rastafari green philosophy and ecological ethic centred on beliefs and practices that are in harmony with nature. Even as observed at their binghis, Rastas want to be as close to nature as much as possible demonstrated when they "sit in the dust" to show their love to Mother Earth. ${ }^{35}$ Essentially, "Rastafari is endowed with visions that advocate 'green' theologies as contextual responses to neo-colonialism and the hypocritical western practices driven by greed." 36 Therefore, Rastafari land use upholds the entire earth as an ecosystem that must be kept in balance through stewardship for the plants; animals and humans are constituent parts of the cycle. Building on what Rastas say Emperor Haile Selassie once said about planting a million trees yearly, ${ }^{37}$ they are in the habit of

between Good and Evil, Zion and Babylon. This is how they encourage one another to build livity or quality life.

34 Interview with Ras John, Marcus Garvey Rastafari House, Harare, 30 May 2014. The term "heartically" is part of Rasta diction to mean "by heart" or "heartily".

35 See, for example, David E. 1998. "Nature in Rastafari Consciousness". Online at: https://debate.uvm.edu/dreadlibrary/david.html

36 Sibanda, "Rastafari Green Philosophy", 187.

37 Sibanda, "Rastafari Green Philosophy", 196. 


\section{Heritage of Land, Water and Great Zimbabwe}

planting trees, which boils down to the sustainable use of land. In addition, Ibo Foroma, a Rastafarian adherent and writer, quoted Emperor Haile Selassie I's command to Rastas towards taking immediate action against deforestation in Ethiopia as far back as 1958. I quote Selassie's instructions at length as captured by Foroma, thus:

It is a matter of great concern for us that the forest wealth which God in His mercy has bestowed upon our country is thus being continually reduced and wasted. Hence it becomes the duty and obligation of every single Ethiopian to become aware of the tremendous industrial and agricultural advantages to be derived from our forest resources, and to practise tree-planting, in order that our hills and planes which have been stripped of their wooded cover may once again be clothed in their green mantle ... The existence or non-existence of forest wealth in a country is one of the most important factors influencing its development and progress ... The increasing pace of de-forestation and the growing dearth of timber in Ethiopia, caused by unregulated tree-cutting and the failure to replace these by new plantings, give us occasion for anxiety that a severe economic problem will confront the coming generation. It is essential that steps be taken here and now to stop this wastage and to check this destruction ... In these days when all nations of the world, in recognition of the tremendous importance of forest wealth, have launched intensive programmes for forest conservation and re-forestation, it behoves our country also to take the appropriate measures to solve this problem. It is our wish and our desire that each and every citizen of our country follow the example we set on this Arbour Day in planting this tree, and himself plant as many trees as he can, for his own benefit as well as for the benefit of future generations. ${ }^{38}$

The above quote illustrates the dangers of destroying forests to the planet and humanity at large. Selassie's warning is cogent since trees are the backbone of life on earth. Some Rastas in Zimbabwe, such as Ras John, have taken the wise words of His Imperial Majesty into action by advocating reforestation in Epworth and the country as a whole. Sizzla Kalonji, a Jamaican Reggae artist who once expressed interest to repatriate to Zimbabwe, was spot on when in his song, "The Planet is in Peril", describes how human activity is destroying the environment, flora and fauna, in the name of "development". 39 This provides many lessons for Rastas in Zimbabwe, who are on record for criticising the cutting down of trees by, among others, newly settled farmers. The key message is that planting trees will save the planet, not the other way round.

The Rastafari thrust toward sustainable land use is behind its practising of organic farming that is a source of Ital food for their vegetarian diet and

38 Foroma I. 2016. "Save the Planet: Plant Trees", The Sunday Mail, 27 November. Online at: http://www.sundaymail.co.zw/save-the-planet-plant-trees/

39 Foroma, "Save the Planet: Plant Trees". 
self-reliance. In a brochure at Chaminuka Rastafari House, the following was noted in relation to Rastas:

We also call for the economic emancipation of the [black] race and support indigenisation. We believe in self reliance, self sustainance, [sic] self awareness ... most of us are blessed with different skills. We also very much support Agriculture since we are vegetarians and we need organic farming to keep our temples [bodies] clean ... Agriculture has always constituted the fundamental source of wealth for the human race. Agriculture is the bloodstream of industries. ${ }^{40}$

The above citation shows that Rastas practice conservative and organic farming that enhances their vegetarian diet. According to Rastafari philosophy for sustainable livelihood, artificial land use pollutes and poisons the soil, water and air through chemicals and fertilisers, to the extent that both land and people are impoverished. Some Rastafarians note that in their small house-yard gardens they are practising organic farming where they grow vegetables and herbs of different kinds which are food-medicines.

On basis of the above, given that the majority of Rastas do not own farms, they are part of urban communities that are utilising house-yard gardens for growing herbal plants for their families. In this regard, some Rastas have developed the interest in growing herbs and acquiring skills in herbal therapy, thereby operating as Rastafari herbalists. ${ }^{41}$ Using limited space, the herbs commonly grown in Rasta herbal gardens include, among others, zumbani (lippia javinica, or lemon bush), gavakava (aloe), tsangamidzi (zingiber officinale, or ginger), mowa (amaranthus hybridus, amaranth or pigweed), guku/tsine (bidens pilosa, or blackjack), garlic (allium sativum), lemon grass (cymbopogon citrates), minthi (menthe spp. or mint), moringa (moringa olifera), chilli/mhiripiri (capsicum annum), onion (allumfistulosum), gwavha (psidium guajava or guava), Mexican marigold (tagetesminuta), mupopo (carica papaya or pawpaw). ${ }^{42}$ Some

40 Chaminuka Rastafari House Brochure. No date. Harare. Rastas see agriculture as a cog-wheel of industry. For instance, horticulture sector production, fruit industry and vegetable production, and flower production could be used for producing Ital food-medicines and other products in order create employment and feed the nation at a time when the country is importing from neighbouring countries such as South Africa. Thus, Zimbabwe needs to improve yields and establish a platform for food security. This Rastafari position is in tandem with that expressed by Nyangore FS. 2016. "We don't need billions to fix agriculture", The Sunday Mail, 21 February, Extra:5. According to Nyangore, Zimbabwe is an agrarian economy with a lot of potential if effectively used and managed.

41 Herbs are any useful plants which can be used in cooking, for cosmetics, to sooth ailments or repel pests. Many fruits and vegetables have herbal properties. Some Rastas enhanced their knowledge on herbs by attending workshops run by NGOs in urban areas. For a closer look at herbs in urban areas, see, for example, MDP-ESA, Herbs for Urban Communities: Safe Plants that can be grown and used by families in Towns and Cities, 7. Online at: http://www.mdpafrica.org.zw/ publications/uaherbs.pdf

42 The Shona terms appear first and the Latin and English versions are in parentheses. 
of these herbs are propagated through cuttings, vegetative methods, runners, root division, bulbs, layering and seed. In order to further maximise the limited space of their gardens in high density suburbs (where most Rastas reside) they use pots to practice container gardening for herbs that can be placed on a balcony. Therefore, Rastas in towns and cities utilise the advantages of growing herbs as they are able to grow them in small spaces, they are easy to grow, are perennials, can grow in poor soil and are productive. ${ }^{43}$ Through observation, the study established that some Rastas establish compost heaps and create mulch using plant matter in their organic farming.

In Epworth, the researcher was shown a well-tendered garden with a lot of bananas, yams and maize (among other crops) that belong to a Rastafari family. The Rastas submitted that they strictly forbid the use of chemicals and artificial fertilisers in their gardens. This is an appreciation and enhancement of naturality that encompassed "conservationism and traditionalism in land use and nourishment strategies". ${ }^{44}$ Hence Rastas are environmental friendly in their land use.

Rastas reason that non-organic farming of cash crops such as tobacco and cotton lead to the use of chemicals and artificial fertilisers that pollute land, water, air and exhaust soils through depleting nutrients. ${ }^{45}$ On contrary, when Rastas cultivate herbs and crops like soya beans, the fertility of the soil is improved and their Ital food supply is environmentally enhanced through organic farming. Rastas also refer to hemp as a crop that is environmental friendly, but currently still classified as illegal under Zimbabwean law. Paradoxically, industrial hemp is on high demand and in use in some Western countries. The cultivation of this crop would enhance national and global efforts to curb the adverse effects of climate change and increase soil fertility besides the economic benefits of hemp products such as textiles, canvas, hemp rope, oil and pharmaceuticals. ${ }^{46}$ This shows that in their practices, Rastas have a lot to teach other nationals on the sustainable use of land just as its management, to which we now turn.

\section{Land management}

Land management among Rastas cannot be separated from land use as overlaps exist. The sustainable use of land through conservative organic farming is complemented through land management that encompasses critical methods that can save soil and water and avoids pollution. For instance, the

\section{MDP-ESA, Herbs for Urban Communities, 7.}

44 Dickerson, "I-tal Foodways", 135.

45 Sibanda, "Rastafari Green Philosophy", 199. Rastas refer to cigarettes as "cancer sticks" in contrast to ganja whose leaves were used for medicine to heal the nations (cf. Revelation 22:2).

46 Sibanda, "Rastafari Green Philosophy", 200. Rastas submitted a project proposal document for the country to cultivate industrial hemp that mirrors the "Hooked on Hemp Project" in South Africa where Rastas conducted experiments on farms with government support. 
use of contour ridges, healing gullies, terracing and strip cropping are not alien practices to some Rastas. They are conscious of the need to save soil, water, trees, grass and wildlife through conservation. As Ras John explained in an interview, Rastas understand that wanton cutting down of trees leads to soil erosion by both wind and water, which led him to develop a passion for taking care of the vegetation at the Marcus Garvey Hills in Epworth. ${ }^{47}$ As part of the care to land, conservation-minded Rastas practice stubble-mulching on their small pieces of land by using plant materials such as leaves and grass, which eventually decompose to form organic matter that makes the soil fertile. According to Rastas, land can also be managed by using grassed waterways. This also protects soil from excessive erosion.

Rastas also pointed to the growing of trees as an agricultural crop that tally with land management. Trees on forestland or farm woodlots must be planted, cultivated, given good care and harvested. Of importance to note is the type of trees that promotes good land management and soil fertility. One Rasta elder expressed concern that exotic trees such as Eucalyptus trees may have the advantage of growing fast, but they do a lot of harm to the soil. These trees impoverish the soils and requires a lot of ground water drying out the land. Rastas also note the disadvantages of Eucalyptus and pine trees, which have poisonous effects on mushroom. Mushrooms that grow in such plantations are inedible in contrast to those that grow under indigenous trees. This is the context in which the Rasta elders seek the promotion of indigenous trees and also advocate the legalisation of hemp, both of which are environmental friendly.

In addition, land management among Rastas includes shunning the use of artificial fertilisers and chemicals on crops. Instead, Rastas they promotes the use of natural fertilisers in the form of organic fertiliser. Research has shown that herbs could be used to improve soil texture and nutrient content of the soil. Moreover, herbs such as comfrey, amaranthus and nettle can be utilised to prepare a strong liquid fertiliser by soaking the leaves for up to two weeks. ${ }^{48}$ The same leaves can be used for mulch or may be added to compost. Pests, such as insects, mice, rats and moles can also be successfully managed on the gardens without resorting to artificial chemicals by using strong-smelling herbs to keep them away or reduce their numbers. Such information constitutes knowledge that some Rastas practice in their house-yard gardens with much success.

As part of their land management, Rastas seek to avoid land pollution. This is done mainly by "environmental arts Rastafarians", ${ }^{49}$ who are into recycling and reusing used material. Indeed, some Nyahbinghi Rastas are reusing and

47 Interview with Ras John.

48 MDP-ESA, Herbs for Urban Communities, 22. The study also revealed that here are dusting powders made from chilli and garlic powder useful in repelling ants, crawling insects and soil pests.

49 See, for example, Sibanda, "Rastafari Green Philosophy", 201; Sibanda, "The Impact of Rastafari Ecological Ethic in Zimbabwe". 
recycling as part of their "Jah works" through which they make works of art from material they collect on the streets and garbage heaps. In this way, they are directly and indirectly managing the carbon footprint that humanity leaves on the environment. By walking the talk to which most advocates of climate change in high echelons of society are just giving lip service, Nyahbinghi Rastas can help to explain the meaning and need for conservation by living and pronouncing practices and laws related to conservation as well as antipollution. Therefore, Rastas can be good partners in land use and management that are environmental friendly.

\section{RETURNING TO EDEN THROUGH RASTAFARI LAND USE AND MANAGEMENT: CRITICAL REFLECTIONS}

The metaphor of "returning to Eden" is employed with the intention of promoting the idea of going back to the beginnings in terms of land use and management. Rastas are fond of the past. ${ }^{50}$ The Garden of Eden was the place where the first human beings resided and lived on a clean environment and natural food. This imagery has implications for Nyahbinghi Rastafari in Zimbabwe. Firstly, in the eyes of Rastas, land is a God-given basic human right that must be restored into the hands of black majority. The Pan-Africanist philosophies of Marcus Garvey and Bob Marley are invoked creatively by Rastas to show that people are their own liberators from oppression. Rastafari is resolute to challenging white and black oppressors on the land question to ensure its eventual equitable redistribution in Zimbabwe. The land question invokes Rasta-State relations, which have different dimensions in Zimbabwe. Secondly, land gives an identity to people and is a source of their livelihood. Therefore, Rastas support organic farming identified as sustainable use of land as well as a source of Ital food and Ital livity. The vegetables, fruits and herbs, which form their diet, grow on the land. This land must be used with wisdom to preserve its fertility and sustain the ecosystem. Thirdly, Rastas possess environmental consciousness. They denounce the reckless cutting of trees under the land reform programme, manifesting among some of the new farmers. This practice is denounced by Rastas without fear or favour. Fourthly, the Rastas are leading the community in managing the environment through "reducing, recycling and reusing", which matches or even surpasses national trends of land management.

50 See, for example, Daynes S. 2010. Time and Memory in Reggae Music: The Politics of Hope. Manchester: Manchester University Press, 197, where anchoring on the past is vital for Rastafari as it is meant for liberation. It functions through identification which is from the present to the past instead of inheritance that comes from the past to the present. However, this anchoring on the past does not imply rejecting modernity because it accommodates a projection to the future. This is applicable to Rastafari views that seek to promote traditionalism and conservative farming as ideal methods identified with the past. 


\section{CONCLUSION}

The chapter has demonstrated that Rastafari is essentially a Pan-Africanist movement that seeks to promote the empowerment and liberation of Africans through land ownership. Both black and white oppressors are criticised on the land question debates in Zimbabwe, particularly those who are multiple farm owners. Rastafari is a relevant player to dialogues on the spirituality and political economy of land, indigenisation and identity in Zimbabwe. The Rastafari "green philosophy" and conservative farming to preserve the soil, as well as to uphold the purity of land and nature by utilising organic farming and shunning artificial fertilisers/chemicals are ideal for national development. Thus, one may conclude that Rastafari values such as social and ecological justice, stewardship and human rights, when applied to the land use and management, promote indigenisation, economic empowerment and sustainable heritage management in postcolonial Zimbabwe. As such, Rastafari perspectives on land use and management can enhance value addition to the knowledge, culture and sustainable development initiatives in Zimbabwe today. 